\title{
Unseen Migration of Young Muslim Girl: The Experience of Critical Thinking Returnee of Ex-ISIS Sympathizers as the Inspiration for Prevention Model of Radicalism in Indonesia
}

\author{
Iklilah Muzayyanah Dini Fajriyah $^{1}$, Kustini Kosasih ${ }^{2}$, Rahmah Nur Fitriani ${ }^{3}$ \\ $\left\{\right.$ Iklilah.muzayyanah@gmail.com ${ }^{1}, \underline{\text { kustinikosasih20@gmail.com }}{ }^{2}$, rahmah.nf@gmail.com $\left.^{3}\right\}$ \\ Universitas Indonesia, Jakarta Indonesia ${ }^{1}$, Badan Litbang dan Diklat Kementerian Agama RI, \\ Jakarta Indonesia ${ }^{2}$, Badan Litbang dan Diklat Kementerian Agama RI, Jakarta Indonesia ${ }^{3}$
}

\section{All authors contributed equally to this work.}

\begin{abstract}
Young girls frequently are not considered as the important subject in analyzing personal involvement as ISIS sympathizer. Nevertheless, young girls has vulnerability and strength simultaneously as significant resources on preventing against extremism. This study conducted since May until August 2020- investigated the migration of 26 Indonesians to Syria in 2015. Using in-depth interview method, focus group discussion, and media literature, the result is analyzed by using Cohen migration theory and Moore \& Parker critical thinking theory. This study also enriches knowledge of determinant factor why young girl migrated to Syria and joined ISIS due to her dream of Medina state in Prophet Muhammad period. Her imagination is challenged by the reality in Raqqa Syria through 3 (three) aspects of critical thinking: truth, knowledge, and value judgement. Verification (tabayyun) on online contents and being realistic in utopian thinking are the important findings obtained in this study.
\end{abstract}

Keywords: young girl, returnee, ISIS, migration, critical thinking

\section{Introduction}

Islamic State of Iraq and Syria (ISIS) sympathizer's recruitment in women similarly carried out on men- using cyber space (1). Social media becomes an effective strategy to internalize ISIS propaganda more quickly, massive, and globally $(2,3)$. An example, the microblogging in Tumblr and Twitter contains persuasive discourse about Islamic state making the reader more curious. An overview of ISIS constructed ideally to create new imagination and influence the majority of young girl to become fangirl of Tumblr and Twitter (4). Interactive and continuous dialogue misguided their logics and deconstruct their thoughts 
about migration dream, leaving their country to settle in new Islamic state- blessed land by God, for the sake of simplistic ideal heaven.

ISIS has build a new perspective of jihad in extreme way- using misinterpretation of Qur'an verses to support their propaganda. Violence interpretation has made the concept of jihad deviate from syariah purposes (Maqashid Syariah) (5)- not accordance with the concept of Islam at all (6). Besides the misinterpretation of jihad, a number of concept strays from Islam are also found. For example, the concept of jihad marriage which is detrimental to women and does not reflect Islamic sharia (7). With convincing language, ISIS propaganda has succesfully uplifting men's enthusiasm to do hijrah as a new internalized ideology. It also affected women in many countries, including one 15 years old Indonesian girl, Salimah. She went to Syria with her big family, hoped to reach heaven in blessed land by God. Beside her uncle and aunt, Salima was the only young girl who actively influenced her family migrated to Syiria in 2015. She threated to went alone to Syria if her father and mother ignored her call. Hence, in August 2015, 26 people consisting 18 men and 8 women, including 3 toddlers migrated to Syiria through Turkey.

Islamic state-utopian build by ISIS, was like an ally for Salima's perspective about Rasulullah madani society. She got this standpoint from multiple books bought by her parents. Long before 2015, she often read books that told stories about how peaceful Moslem citizen was in Madina, under Rasulullah's leadership. Salimah explored her Islamic understanding over the internet, and she was drowning deeper in ISIS propaganda through social media, after her introduction to ISIS by her uncle. Salimah's will to have a Madina-life of Rasulullah, as if it can be realized through ISIS, made her strengthen determination to migrate to Syiria. She also persuaded her family to go Syiria so she would enter the heaven together with her family (Interview, 24 July 2020).

When she persuaded her family to do hijrah to Syiria, as teenager Salimah was not thinking on how to become jihadis, combatants in war zone. Her imagination was pretty simple, move to Syria with hope to find better God blessed-life. She imagined good life with proper health facility, free education and job opportunity with better pay compare to Indonesia. ISIS even promised to pay all the transportation costs from Indonesia to Syiria (Interview, 24 July 2020).

Even young girls count as targets by ISIS, yet young girl's ISIS research has not drawn much attention for Indonesian researchers. ISIS research in Indonesia mainly focused on men engagement on ISIS (8). In the meantime, research on women mostly shown woman position and role on ISIS. Refer to several research (9) they describe ISIS woman position as mentioned in Spencer's (10), namely as recruiter, mother, wife, head of command, overseer, student, prison guard, doctor, patrol officer, and combatan.

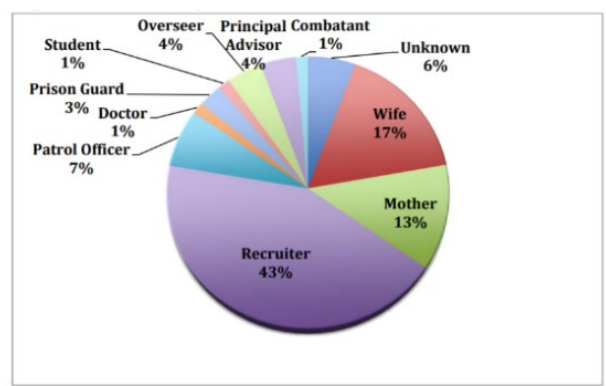

Figure 1. The Primary Roles of Women in ISIS (Spencer, 2016) 
This research purposely analyzes young girls engagement on ISIS, as an effort to discover effective strategies to shield young girls's vulnerabilty from extremism. This research also learns how uncontrolled use of social media on young girls can transformed life of a family significantly. A father, a mother, and sisters were exposed on ISIS propaganda, just because of a request from one immature girl. This study can give us a new picture on how family's involvement in ISIS was not just initiated by man as the head of the family, but also can be triggered by simple dream of a girl. Taking into consideration of young girls as subject of ISIS recruitment does become an important study.

Beside the negative impacts brought to the family, this study also give us important knowledge in the opposite context. A young girl who realized her mistake on plunged her family in ISIS, could encouraged herself to take responsibilities and struggled to find way back home. This young girls's experience could become reflected knowledge to invent model and strategy on counter-radicalism and counter-extremism, especially in Indonesia. Refers to those goals, this research aims to focus on 3 (three) research problems, namely (1) How did young girls could trapped on ISIS propaganda and do hijrah with her family to Syria, (2) How was a young girl ISIS returnee did the critical thinking process, so that she took a decision to go back to Indonesia, and (3) What learning that can be obtained from a young girl's experience, who did migrate to Syria and became an ISIS returnee?

\section{Method}

In this paper, we presented policy research using study case qualitative methods. Narration in this study is a story based on Salimah's experience, a fifteen years old Indonesian girl. The story captured Salimah's journey from Indonesia to Syiria, lived in small ISIS town named Raqqa for almost two years, and then cameback to Indonesia as ISIS returnee. This research was conducted in one of the cities in Java within four months-period, May - August 2020. The data was collected using 3 (three) techniques, which are: (1) focus group discussion with Salimah's mother, sister, aunty and cousin, (2) depth interview with Salimah and her counsellor, and (3) media content search about the Salimah's story, with Salimah's real name as keyword. Salimah is an alias name, created for ethical and safety consideration.

This research is analyzed using 2 (two) theory, migration theory and critical thinking theory. Robin Cohen's migration theory (11) is a basis on how to understand unsingular and interelated complexitiy. Some variant in Cohen's theory explained Salimah and her family's migration, and at the same time tested it through reason in decision making. Cohen elaborate migration in a variety of expressions, in a form of 'asymmetrical dyads', with stressed on one aspect compare to the to others. Asymmetrical dyads can be observed from the 9 following: individual vs contextual reasons to migrate, rate vs incidence, temporary vs permanent migration, settler vs labour migration, planned vs fligh migration, economic migration vs political refugees, illegal vs legal migration, dan push vs pull factors (11). Cohen's theory is strengthened by teory migration developed under Cohen's thinking by Russell King (12). Asymmetrical dyad must be critically used, especially on migration that occurs among countries (international migration) as Salimah did. King also remids that migration is happened in spesific space and time, so it is important to clearly define it in distance and time the migration was conducted. Someone's international migration can not be seen to what appears as shift between countries only, it also included the problem of migran's statistic that often become the iceberg phenomenon because of illegal migaration case like Salimah's. Therefore, Salimah's study is analyzed using the advanced of migration theory, spesifically using asymmetrical dad's forced vs voluntary migration (12). 
Critical thinking Moore and Parker's theory (13) then confirms the migration by Salimah. This theory explains how Salimah and her family built logic on decision making process, how they reflected their life in Raqqa and so they took decision to return to Indonesia. Claim, issued and argumentation that Salimah built can explains how her critical thinking process has actually appeared before Salimah decided to migrate. Three aspects of critical thinking namely truth, knowledge and value judgement then made her find a turning point when she faced the real ISIS facts in Raqqa. This study is not just about women, but this is a women's perspective study (14). This research is intentionally made Salimah as the main subject of research. Salimah's journey is not only be a reflection for theoretical importance, but also as a first step to find strategic ways on counter radicalism. Knowledge, experience and women's actions is are much as important as men. Women and their life are not positioned only to be part of the context of men's experience.

\section{Result}

The narrrative in this study describes three main aspects of Salimah's experience with her family. Salimah's journey story begins when she dreamed of Medina led by Rasulullah, then Salimah and her family traveled to Syria- continuing their life living in ISIS territory. It ends with their struggle to leave the ISIS territory and return to Indonesia. The significant learning coming from Salimah's deep reflection about her experience is discussed at the end of this article.

\subsection{The State of Medina vs the Blessed Syria}

In 2015, Salimah turned 15 years old. The second daughter of three sisters likes reading and spending time alone with gadgets. Salimah's solitude is reasonable. Her older sister- not far from her age, did not live with her. She had been living in a boarding school in Malaysia for more than 3 years to pursue high school and university education. Meanwhile, the younger sister spent more time with mother rather than playing with Salimah. Salimah spent her days attending school, studying, reading, taking additional tutoring, and playing with the internet- common activities experienced by teenagers at that time.

Her hobby made Salimah interested in the Apostle's story. Salimah's father, a wealthy director of a company in border town of Indonesia and Malaysia. He is responsible for managing foreign investment in Indonesia. With the established position, Salimah's parent facilitated all her needs and pleasures, including providing Sirah Nabawiyah books in several volumes. Salimah enjoyed the story of Prophet's life in those books. At that time, Salimah only cared about the book content. She did not care about the author and the publisher's ideology. She never thought could get lost by reading those books. She was increasingly immersed in the image of ideal state presented in books and began to compare with the Indonesian government. The reading made Salimah more critical in seeing social phenomena, but also experiencing fallacies simultaneously (15). Otherwise, in her reflection, she felt the difference between Islamic governance in Medina and Indonesia. Her critical perspective to social phenomena began to emerge, particularly on social injustice she witnessed on television. In the exclusive interview for more than 6 hours, Salimah said, if she heard social injustice news due to the inequitable social relations at that time, she became more volatile. For instance, Salimah began to compare the punishment for the old lady stealing branches in the forest to survive with the light punishment for the corruptors. This injustice tickle Salimah's critical thinking. 
Along with this situation, Salimah simultaneously experienced the fallacies in her thinking triggered by her emotional feelings. The fallacies is frequently triggered by anger against the injustice, pitiness/compassion, spite or jealousy, guilt, even hope or desire which can direct one's thinking to take wrong response/action (15). This condition seems to be used by ISIS sympathizers in the recruitment efforts. The potential victims assumed as if making the right decision joining ISIS- motivated by their critical thinking towards injustice; they tried migrating to country with justice. This condition is regularly seemed in women from varied countries who joined the ISIS caliphate $(16,17)$.

At school, Salimah was a cheerful girl and often joking with friends. She made many friends. She is also smart- often got best ranked in class. One day, she reunited with her junior high school friends. She frequently greeted them through social media. They had changed wearing a headscarf (jilbab) and covered up, but still fashionable. Salimah was interested in the dress style. She felt that dressing like her old friends is peaceful and trendy. The fashion was women wearing long-sleeved shirts with denim skirts and headscarves as usual (not big and wide headscarves). This interest led Salimah to learn about Islam and search for Islamic references in the cyberspace. While studying about Islam, she was not accompanied by anyone. The bussy parent made them miss in monitoring websites Salimah visited for searching Islamic information.

The strong empathy against social injustice practices and the interests in Islamic discourse are a series of experiences reinforcing Salimah's imagination to the ideal state through an Islamic legal system. The utopian grew stronger after her uncle told about ISIS. He told ISIS as the great and had declared the caliphate in Syria at the end of 2014. Since then, Salimah's imagination of Medina during Rasulullah period seemed real. She explore more information about ISIS; she was increasingly immersed in the discourse ISIS had built in the online media. She initially searched about ISIS through Facebook. The interactions on Facebook provided illustrations about the positive experiences of people who lived under ISIS caliphate. She also got other ISIS propaganda network sites. Salimah continuously followed the current discourse through other social media, mainly in Tumblr and Diary of Muhajirah channel (Diary of Women who Migrate). Salimah did not recognize; she was caught in the media controlled by ISIS, mostly tumblr. Some studies show tumblr is a online media substantially dominated by ISIS propaganda. It succeeded in influencing many women mainly the young to join ISIS $(4,18,19)$. Besides Tumblr, Salimah was inspired by 3 Muslim girls aged around 16 year old from Western countries who migrated to Syria in Diary of Muhajirah channel- containing experiences of people who 'migrated' to Syria. As if looking in the mirror, Salimah felt that she could do similarly. With good English skill, she communicated intensively with ISIS sympathizers on varied social media. The deep interaction between Salimah and ISIS sympathizers convinced her that all ISIS propaganda is the truth; any discourse against ISIS is slander.

Salimah changed; she was no longer cheerful at school. She spent more time reading and exploring the utopian about ISIS. Her school became a mess, and her report cards had greatly down, but she did not care. Furthermore, she wrote a letter to her mother and asked moving from formal school to home schooling. She had fallen in love with ISIS- not due to the offer to war and becoming jihadist, anti-infidel, or hating Indonesia; her thinking was simple. She wanted to feel the peace of life in the heaven land- blessed by God with a leader following the Prophet's leadership. Salimah forced her parent to migrate to Syria. Her father, known as a friendly and good man, refused his second daughter's request. Yet, Salimah never stopped sulking and threatened going alone. For her wish, Salimah left home as her strategy to convince her parent; she finally succeeded. Constantly reassured by his daughter, Salimah's 
father also searched information about ISIS and discussed with his wife and other families. One significant source provided information about ISIS propaganda to Salimah's father and family was the uncle. The propaganda continuously internalized to Salimah's parent succeeded. They had been influenced, even Salimah's mother had been actively posting news about ISIS on her Facebook account. They also agreed to migrate to Syria and began to prepare in large groups of 26 people.

\subsection{Migration to Syria: Heaven and God's Commandments}

Salimah moved to Syria. In Viano's (19) study, women migrating to Syria are not always for contributing to the horrific ISIS war. For Western women, migrating and joining ISIS do not always reflect hatred against Western culture and lifestyle (20). Sometimes, women migrated to Syria with positive goals, although in the shadow of ISIS propaganda. They migrated to actualize the concept of Islamic state with a new vision of an ideal Islamic state. The above is similar with Salimah's experience. ISIS propaganda provided new imagination of living in a country embodied with peaceful Islamic values; it made Salimah in love with ISIS caliphate. Through the massive propaganda on the internet, ISIS offered a life full of God's blessings with luxurious and ideal standard of living. Free education and health facilities, a choice of work with high salaries, and comfortable housing with free electricity and water were some promises in the ISIS campaign which Salimah received. ISIS also made a false promise to reimburse all travel costs spent by Salimah if she migrated to Syria. Furthermore, ISIS also stated men were not obliged to fight in a war and could be protected as the civilians.

The persuasive that Salimah continuously received through online media built new hope. Her love for the Islamic state offered by ISIS seemed to strengthen her critical logic against the social injustice. These positive goals strengthened Salimah to invite her entire family migrating to Syria. In the exclusive interview with Salimah, her statements described that migrating to Syria is not only for Islamic life, but also a part of God's commandmentwith heaven as the final estuary.

"In the Qur'an, it is explained that we must migrate to a land blessed by Allah. [...] Thus, I didn't want to go alone. I want to invite my family because I don't want going to heaven alone. I want my family go with me and live in a land blessed by God. " (Salimah, Interview, 24072020)

Salimah's thoughts are accordance with several thoughts of women who joined the ISIS caliphate. Positioning ISIS as the life goal in the world, enjoying a luxury and glamour life in "ISIS lifestyle" (Anita Perešin, 2015), building a new caliphate as a part of Muslim's obligation, and finding the new "caliphate sisterhood" (17).

For these women, building a Muslim caliphate is not only something very desirable but an obligatory religious duty. In other words, they believe that building an Islamic state is a must for every Muslim. Migration then becomes an obvious duty. Completing these duties is essential to obtaining one's seat in heaven. A strong belief in the afterlife is a powerful motivating variable both for the ISIS men in combat and for the women in a supportive role. Thus, the migration from an infidel Western country to a pure Islamic state is seen as moving to the threshold of heaven. (19)

Then, Salimah's parents made the departure, preparing the costs for the international trip. They sold assets: house, car, motorbike, and house property. Meanwhile, the technical 
preparations were under her uncle's command; the uncle is the older brother of Salimah's mother. He also communicated directly with ISIS and arranged all travel plans for Salimah's extended family (Nguyễn Đình 2019). Salimah did not know how he communicated with ISIS. Yet, the online network facilitated the illegal migration process carried out by ISIS network in recruiting the prospective members. They will provide information, coordinate, organize, and supervise the entire journey, until reaching ISIS territory (19). On 1 August 2015, Salimah with 24 relatives and a colleague of her father flew from Soekarno-Hatta airport to Istanbul Turkey then to Syria. In Salimah's mother story, her father was actually hesitant migrating to Syria and staying there forever. Therefore, at the departure time, he did not resign from his job. He only applied for leave- scheduled to work on September 2, 2015. He complied his second daughter's wish migrating to ISIS land due to his concern for Salimah who could be desperate going alone. He never thought becoming a war jihadist; he only intended to be a civilian as in Indonesia.

"I initially had doubts, [...] So, finally I said, 'We'll see, if it's not good, then we back'," [...] (but) "The reality is not like that (ISIS promises are false). " Salimah's father, 19072019

There was almost no obstacles in Salimah's journey to Syria through Istanbul. Her uncle manipulated by using false information as a traveling tour. Salimah and her family enjoyed the traveling in Turkey as tourists. Before crossing into ISIS territory, they stayed several days in some hotels in Istanbul. They must move to several cities every few days. Everything was carried out under ISIS instructions which continuously monitored via phone. To fill the leisure time, they walk around several tourist attractions and behaved like a tourist. They were in Turkey for more than two weeks.

After ISIS confirmed, they was dispatched to Syria illegally. They were divided into 4 groups with 6-8 people/group. Salimah was in the second group with her father, mother, and her sisters. As they crossed the Turkish-Syrian border, they had a journey they never imagined. They must sneak around, walked in the dark of the night for more than 5 hours, groped, fell, stumbled on sharp rocks, and explored difficult and heavy fields. At the following nightfall, Salimah's group and 2 other groups arrived in Syrian territory, but the first group of 7 men failed and were caught by the Turkish security forces. When Salimah arrived in ISIS territory, she felt passing a noble struggle for migration (hijrah). She was grateful for achieving her dream living in a blessed land. She immediately kissed Syrian border land and bowed happily.

In ISIS propaganda, Syria become the destination country for Salimah's migration. Syria was a pull factor for Salimah, not only due to the claim as the 'blessed land'. ISIS propaganda contained the false promises of Islamic life in Syria strengthen the position as destination country for individual migration. This pull factor is reinforced by a complex push factor in Salimah self. Solitude, utopian life in Medina, the absence of parent, peace in the way of dressing, and reflection against social injustice became the complexity of problemstriggered the presence of push factors to migrate. None of single push factor in the context of women's migration to Syria. Likewise, the push factors for women joining ISIS are due to the unemployed women (21), economy, political violence, state repression (22), Islamophobia, resistance to parents, perceived as the victims in Western countries, feeling honored as female jihadist (18), alienation sense; those reflect the complexities. Therefore, looking at push-pull factors on women's migration is not enough by only identifying the facts without explaining the complexity. In this case, the opinion of Jacobsen (23) is important as the key note of discussion, that 
"The general criticism of push and pull factors are based on the fact, that these do not explain why some individuals are affected by these factors and become radicalised, while others who are experiencing the same factors do not. [....] The factors vary depending on the individual and are often a cumulative process taking place simultaneously on micro-, meso- and macro-level.” (23).

\subsection{Come and Go from Raqqa}

The life reality triggers the presence of critical thinking awareness in people, even though none link with their life. When a reality is not in line with the dreams and hopes, people can experience two different conditions. First, keep them alive in the fantasy world. They will continue to search the logic of justifying the unexpected reality as pending dream or interpreting facts differently. This condition will continually immerse people in the false consciousness of utopian world constantly created- the reality is forced in line with their imagination. Second, becoming an opportunity for critical thinking awareness. The utopian is continuously confirmed through intense interaction with the real world. Every occurrence in the real world becomes the experience evaluated based on the fantasy world.

In Salimah's story, the second situation seems to be experienced by Salimah and her family. The imagination of utopian Islamic state with facilities for education, health, and employment is continually confirmed by facts found while living in ISIS territory. Several facts far from the ISIS propaganda bring new awareness to stop dreaming of prosperous and peaceful Medina state. Facts in the daily life not in line with Salimah's religious understanding have prompted Salimah's extended family to decide returning to Indonesia. Salimah's critical thinking awareness is growing. The rejection of ISIS concept emerge along with the evaluative thoughts on religious practices during her stay in Raqqa- a city under ISIS rule. This condition strengthens Salimah's critical thinking ability where rejection and acceptance of an argument, idea, concept becomes the conclusion sustained by deductive, inductive, and evaluative thinking (24). A series of new life experiences are reflected. Salimah got four fundamental factors sustaining her self-awareness and extended family to end the bad experience of living under

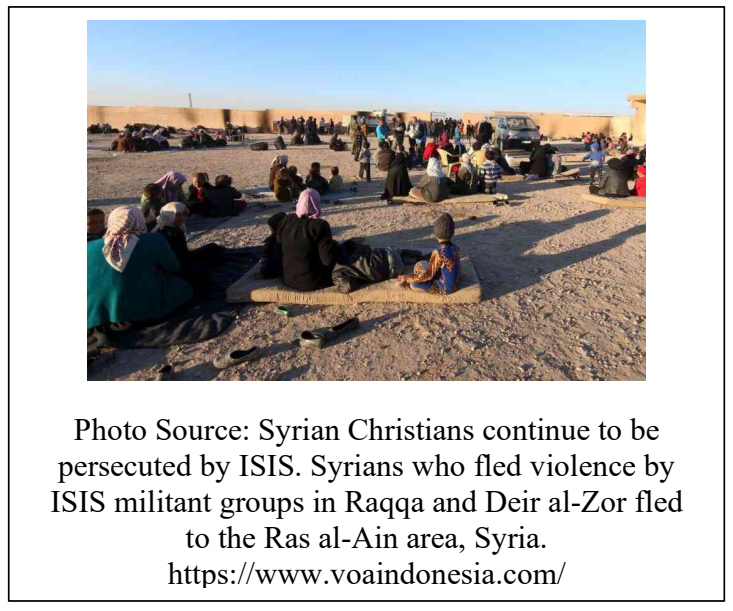
ISIS rule, namely economic factors, policy and legal factors, discrimination and violence factors, and religious practices.

In Raqqa, the life of Salimah and her family was far from ideal. His father could not work and could not get a decent job as promised. They also did not receive any financial support from ISIS because none of the men in Salimah's family were willing to become jihadists. They did not get facilities including financial security for daily life when becoming civilians. The women of Salimah's family must work- selling clothes and headscarves in makeshift markets. Men must hide so that not to be forced joining the war. In forced situation, women sold the gold jewelry they worn, until none left. Salimah and her family faced serious economic problems. 
They always tried asking for ISIS promises. They took legal efforts, although they ended in vain. Salimah and her 2 aunts tirelessly asked promises. They sent report letters, application letters, and even letters of demand directly to several ISIS legal service offices. They also must ask someone to translate their letters into Arabic so that those could be accepted. The process demanded a tremendous amount of patience. Entering an ISIS office and not seeing an officer, waiting for hours without success, a letter being received and no following-up, or being ordered to hand over the letter to another office with no officer is a real bad experience. This legal process must be carried out by Salimah and her two aunts, because they have good English skills, and it was impossible for men due to the risk of being forced to fight in a war.

Discriminatory attitudes can be found in all areas- market, internet cafes, around residences, and shopping areas. Discriminatory attitudes are also very visible towards the indigenous communities. Robbing property belonging to indigenous people is a common thing. As a result, they were forced to move to other areas- to leave ISIS territory. Their assets and livelihoods were forcibly robbed by ISIS. The practice of social life also does not reflect peaceful Islamic values. Varied unfair actions can be seen clearly towards the indigenous community- the inhumane sanctions (takzir) mechanism and the ways of communicating full of violence. Those become daily experiences that Salimah saw- dispute over trivial things frequently seen, dispute in the neighbourhood always using harsh words, shouting each other, and even using sharp objects such as knives. Torturing the accused residents violated the rules was applied inhumanely. The bodies of those executed were left lying on the streets with separated heads. Girls are not allowed to mature in good education. Child marriage is usual. Salimah's parents repeatedly rejected proposals by ISIS soldiers who wanted to marry Salimah, her older sister, and younger sister.

Each occurrence showing violence made Salimah's family continuously question the concept of ISIS Islamic State which they learned from social media. It is not only civilians who show the ways of life far from Islamic values. ISIS officials are also unfriendly, rude, violent, and have sadistic attitudes. They are far from being an Islamic leader, who is friendly, fair, full of love, and has "morality". Every occurrence not in line with the Islamic understanding of Salimah's family strengthening Salimah's critical thinking awareness. Truth and knowledge have led Salimah to a firm value judgment. She concluded; there are no Islamic values reflected in Raqqa. The participatory observation coincidentally carried out by Salimah became a source of reflective information for her critical thinking. Salimah and her family took the decision to end the dream of the state of Medina, a blessed land, and heaven on ISIS teritory. They considered returning to Indonesia. Salimah realized Indonesia was a blessed country. Although Indonesia is not perfect, Indonesia is a country that offers a peace of life that Salimah never found in Raqqa- ISIS territory. Decisions based on the ability to get reasonable, realistic, rational, and firm conclusions is one of the characteristics of critical thinking ability Salimah has obtained (Padmanabha C.H, 2018). 
Salimah and her family began planning to escape from ISIS territory. They were looking for people who could help escaping from ISIS territory. For almost a year, they had continued to struggle escaping from ISIS's bonds. The struggle returning to Indonesia had also experienced of being deceived by people offering services to escape from the ISIS border area. This deception was very expensive and almost spent the remaining assets of Salimah's family. After being deceived three times, Salimah and her family succeded to leave Syria. On June 10, 2017, Salimah succeded to cross the ISIS border through a long, hazardous, and lifethreatening journey. Gunfire from Kurdish soldiers almost took Salimah's family lives. Entering Kurdish territory in Iraq, they were forced to become the prisoners of Kurdish soldiers. Women and children had to live in prisoner of war areas in heavily guarded refugee tents, while men had to stay in prison for several weeks.

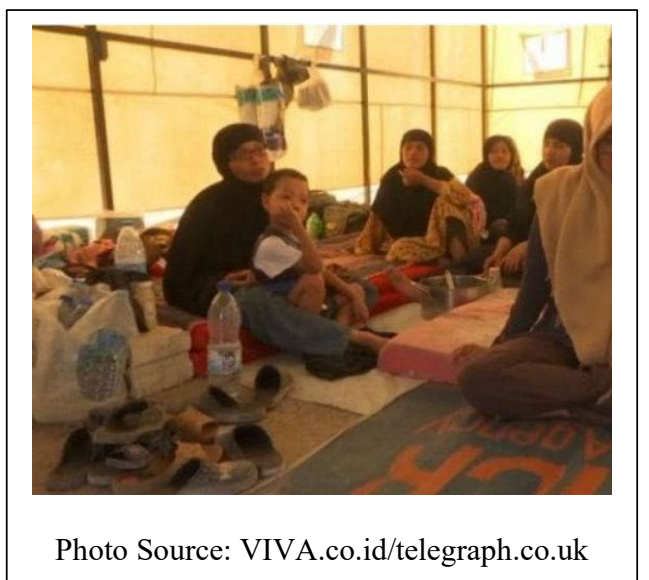

While living in Kurdish-controlled territory, they continued to struggle finding ways returning to Indonesia. The presence of journalists is an important moment for Salimah and her family. Through the international media coverage, their position were discovered by the Indonesian embassy in Iraq. With the help of Indonesia authorities and an Indonesia NGO working on terrorism issues, they were able returning to Indonesia. On 12 August 2017, Salimah and 17 remaining family members were picked up by the Indonesia authorities. They were flown back to Indonesia from Doha- Qatar to Indonesia using a Qatar Airways plane.

Salimah breathed Indonesia's peaceful air on Saturday at 15.45 WIB (25).

\subsection{Tabayyun as the Dead Price}

The almost 2 years of migration experience has provided very important lessons for Salimah. Her decision of migrating to Syria was due to the ISIS propaganda through cyberspace. As if being hypnotized, she firmly believed in the truth of the news about ISIS. Any information that "disfigure" ISIS was considered as the slander launched by the ISIS enemy. She never went deeper into tabayyun because ISIS propaganda had eliminated her realistic logic of thinking. Salimah, only a teenager, was in a psychologically unstable condition. Like a teenager in love, Salimah was immersed in false information circulating in the cyberspace without verifying the truth first.

Cyberspace and internet have been used as a platform of propaganda and brainwashing in spreading radical ideology. The Internet has a very significant potential to be the accelerator of radicalization towards the users. They tend to get the courage to join radical groups after obtaining certain information via internet (von Behr et al. 2013). The internet has also become an effective medium of influencing the unstable conditions of teenagers to join the ISIS network $(4,18,19)$. Therefore, tabayyun (checking and re-checking) of information obtained from cyberspace is an action that cannot be ignored. Tabayyun is a dead price. If it was not carried out, the internet has the potential as the real path of misleading information for anyone. This was admitted by Salimah and her family. 
"This is a valuable lesson for us so that in the future, we do tabayyun first. We found a reality far from the hopes and dreams of an ideal Islamic society. The reality is very different and we are totally deceived "(Salimah, 24072020).

"In Surah Al-Hujurat verse 6, Allah commands us to always check the news that comes; so not to harm a people due to our ignorance. After that, we asked people who knew better, whether it was government officials or religious leaders. " (26)

Tabayyun leads person to acquire critical thinking skills. With tabayyun, information is not easily accepted. The truth of information is traced carefully. This situation leads to enrich knowledge about something. Through critical thinking, ISIS propaganda will be confirmed as an outright lie. The concept of khalifah Islamiyah (Islamic state) offered by ISIS is a nonsense concept in today life reality. Finding conclusions based on comprehensive knowledge can lead to the strong reasons for right decision-making process. At this time, a person is able to critically think and properly save their future.

"There are many ideas of radicalism on social media even though they are offline. Then, young people as the millennial generation can't be far from social media so that we must be able to have shield for ourselves when playing social media. One way is to think critically, to improve our critical thinking. So, if the narratives a bit strange, spreading hatred, we should criticize it first, is it true? (26)

Besides the importance of tabayyun as a step towards critical thinking skills, Salimah's experience also provides the important reflection of family management. Salimah's parents have realized the importance of parent's role in fortifying children from radicalism. Parents must facilitate their children with appropriate information sources, assist them in understanding religion, and monitor the learning resources that their children access. Facilitating internet for children must be complemented by strengthening children's ability with critical thinking. Parents must provide time to assist children in reading critically on any information and knowledge they obtained. Parents should take a central role in supervisory patterns, provide active mediation- coviewing mediation, or limit children's internet experiences. A quality approach to communication between family members and prioritizing the warmth of relationships is an important method in developing authoritative supervision patterns without being permissive (27).

\section{Conclusion}

Salimah's experience illustrates two important things; first, the excessive desire to live in the state of Medina to build a critical awareness of inequitable legal system practices. However, the excessive emotional feelings against inequitable legal system misled Salimah from the real logic of critical thinking and trapped her in ISIS propaganda without carrying out tabayyun process. Emotions are confirmed as the situations which can mislead person from critical thinking ability. Second, Salimah's life experience in Syria has been able to rebuild her critical thinking ability. She realized the logical flaws, observed the deceits through the facts, and gathered additional information by observing around the city of Raqqa. Salimah built new arguments based on the results of her participatory observation and used her life experiences as the reflective and evaluative way. Salimah's critical thinking logic led her to the belief in new truth values based on the strong knowledges. This critical thinking ability led Salimah to a realistic, rational and firm decision returning to Indonesia. 
Tabayyun is the key word of the most important lesson Salimah learned. Tabayyun on all information obtained is non-negotiable. For Salimah's parents, this family experience reminds the importance of having parents on each days of child's lives. Facilitating children with a number of learning support facilities such as books and internet access without supervision and support for critical thinking skills can potentially put children in danger. The risk of unsupervised internet access to children is not only dangerous in the context of radicalism, but a number of other dangers, such as sexual violence, drugs, and other cyber crimes.

Salimah's experience in the narrative also provides a clear evidence of the spread of radicalism ideology and propaganda through cyberspace (cyber radicalization). Cyber radicalization has the potential to create radical individuals without directly affiliated with radical groups. In the effort to prevent radicalism, the same strategy is important. The use of internet platform, mastering discourse on social media, and involving young people are important inspirations in the efforts to prevent radicalism in Indonesia. The field of information technology must be systematic, massive, and integrated to carry out the same strategy as the critical thinking approach. This effort is important because cyber attacks are a serious threat to Indonesia; since Indonesia is included in the list of vulnerable country to cyber crime, including radicalism (28).

Teenagers are the targets of radical group propaganda. ISIS provides significant roles for young girls (10). The unstable psychological condition increases the vulnerability of young people to engage in radicalism networks, including young girls. In prevention efforts, measuring the vulnerability of young people including young girls is an important step. Salimah's experience shows that youth does not show the weakness. Salimah's role is very significant, not only in the context of her ability to influence adults to engage in radical networks, but also in her reliability in struggling and finding ways of disengaging from radical group networks.

Ignoring women and omitting the importance of women's involvement in radicalism networks unexpectedly relate to the strength risks of radical group networks. Support and participation of women in radical groups is not only due to women's subordination to men's decisions, but it can be the result of the discovering process of their personal beliefs and experiences (29). The complexity of women's lives shows the push factors for women's migration to the teritory of radical groups are neither single nor simple. Therefore, the same perspective is important to use in the prevention and deradicalization efforts. Positioning women as important as men and giving a strategic role to women in prevention and deradicalization efforts becomes the right decision, both for adult women and teenagers.

\section{References}

1. Viano EC. Introduction to the Special Issue on Female Migration to ISIS. Int Ann Criminol. 2018;

2. Rachmawati T, Karisma G. Konstruksi Identitas ISIS Melalui Digital Media "Youtube" di Indonesia. POLITEA. 2018;1(2):125.

3. Nainggolan PP. Ancaman ISIS/IS di Indonesia. Vol. 21, Kajian. 2018. 177-199 hal.

4. Ben-Israel GM. Telling a Story Via Tumblr Analytics: Europe's Young Muslim Female Attraction to ISIS. Int Ann Criminol. 2018;

5. Aulassyahied Q. PROBLEM OF ISIS'S QUR'ANIC INTERPRETATIONS AND CLAIM OF THE IMPLEMENTATION OF SHARIA LAW. IJISH (International J Islam Stud Humanit. 2019; 
6. Sandberg S, Colvin S. 'ISIS is not Islam': Epistemic Injustice, Everyday Religion, and Young Muslims' Narrative Resistance. Br J Criminol. 2020;

7. Permana IM. Jihad Marriage for ISIS Women in Indonesia. Islam Universalia. 2019;1:213-27.

8. Ramdani F. 300 Hari di Bumi Syam Perjalanan Seorang Mantan Pengikut ISIS. Jakarta: Milenia; 2020.

9. Leebarty Taskarina. Perempuan dan Terorisme Kisah Perempuan dalam Kejahatan Terorisme. Jakarta: Elex Media Komputindo; 2018. 168 hal.

10. Spencer AN. The hidden face of terrorism: An analysis of the women in Islamic State. J Strateg Secur. 2016;

11. Cohen R, Robinson V. Theories of Migration. Popul (French Ed. 1997;

12. King R. Theories and typologies of migration: An overview and a primer. Willy Brand Ser Work Pap Int Migr Ethn Relations. 2012;

13. Moore BN, Parker R. Critical Thinking. Ninth Edit. Michael Ryan, editor. New York: McGraw-Hill; 2009.

14. Moore HL. Feminisme dan Antropologi. Jakarta Obor. 1998;

15. Nusarastriya YH, H HS, Wahab AA, Budimansyah HD. PENGEMBANGAN BERPIKIR KRITIS DALAM PEMBELAJARAN PENDIDIKAN KEWARGANEGARAAN MENGGUNAKAN PROJECT CITIZEN. J Cakrawala Pendidik. 2013;

16. Perešin A. Fatal attraction: Western muslimas and ISIS. Perspect Terror. 2015;9(3):21-38.

17. Pooley E. A New Sisterhood: The Allure of ISIS in Syria For Young Muslim Women in the UK. ProQuest Dissertations and Theses. 2015.

18. Kneip K. Female Jihad - Women in the ISIS. Polit IAPSS J Polit Sci. 2016;29:88106.

19. Viano EC. Introduction to the Special Issue on Female Migration to ISIS. Int Ann Criminol. 2018;

20. Bjørgum MH. Jihadi Brides: Why Do Western Muslim Girls Join ISIS? Glob Polit Rev. 2016;2(2):91-102.

21. Xharra B, Gojani N. Understanding push and pull factors in Kosovo: Primary interviews with returned foreign fighters and their families. Indep Comm Report Prishtina, Kosovo United Nations Dev Program. 2017;

22. Schmid AP. Links Between Terrorism and Migration: An Exploration. Terror Counter-Terrorism Stud. 2016;

23. Jacobsen A. Pushes and pulls of radicalisation into violent Islamist extremism and prevention measures targeting these: Comparing men and women. 2017;

24. Padmanabha CH. Critical Thinking: Conceptual Framework. J Educ Psychol. 2018;11(4):45-53.

25. Qodir A. 2 Tahun Hilang, Satu Keluarga Mantan Pejabat Batam Masuk "Rombongan" 18 WNI yang Kabur dari ISIS [Internet]. tribunnews.com. 2017 [dikutip 20 September 2020]. Tersedia pada: https://www.tribunnews.com/nasional/2017/08/14/2-tahunhilang-satu-keluarga-mantan-pejabat-batam-masuk-rombongan-18-wni-yang-kaburdari-isis?page $=$ all

26. Susilo J. Pengalaman Nurshadrina Khaira Dhania, mantan Returnis ISIS yang pernah ke Suriah [Internet]. antaranews.com. 2019 [dikutip 20 September 2020]. Tersedia pada: https://bengkulu.antaranews.com/berita/85911/pengalaman-nurshadrina-khairadhania-mantan-returnis-isis-yang-pernah-ke-suriah 
27. Adi TN. Pola Pengawasan Orang Tua terhadap Aktivitas Anak di Dunia Maya: Studi Kasus pada Keluarga dengan Anak Remaja Usia 12-19 Tahun di Purwokerto. Acta DiurnA. 2017;13.

28. Lubis RR. INDONESIAN INTERNET USERS POTENTIAL IN COUNTER-CYBER RADICALIZATION. J Pertahanan Bela Negara. 2017;

29. Chowdhury NF, Shetret L, Barakat R. The Roles of Women in Terrorism, Conflict, and Violent Extremism. Cent Glob Counterterrorism Coop. 2013; 